\title{
THE LEGAL NATURE OF REMUNERATION FOR PERIODS OF RELEASE FROM THE OBLIGATION TO PERFORM WORK FOR TRADE UNION ACTIVISTS
}

\begin{abstract}
In this article the Author analizes the issue of legal character of trade union activists released from work, covered by employers. The Author underlines the latest extension of subjective rights in this matter by Polish legislator to other than an employee persons who perform gainful work. In her opinion the remuneration for work, paid by employers at abovementioned basis may be qualified as work-related benefits of a social (even public) nature. In her opinion the current regulations in this matter are questionable in the light of the principle of the independence of trade unions and the principle of proportionality.
\end{abstract}

Keywords: trade union activist, remuneration, employer, gainful work, proportionality.

\section{CHARAKTER PRAWNY WYNAGRODZEŃ ZA OKRESY ZWOLNIEŃ OD PRACY DZIALACZY ZWIĄZKOWYCH}

Streszczenie. W ramach artykułu Autorka analizuje kwestię charakteru prawnego wynagrodzeń dla działaczy związkowych zwolnionych z obowiązku świadczenia pracy, których koszty pokrywane są przez pracodawców. Autorka zwraca uwagę na ostatnie rozszerzenie przez polskiego ustawodawcę uprawnień podmiotowych w tym zakresie także na inne niż pracownicy osoby wykonujące pracę zarobkową. Jej zdaniem wypłacane przez pracodawców wynagrodzenia z tych tytułów można kwalifikować jako świadczenia związane z pracą o charakterze społecznym (a nawet publicznym). Aktualne rozwiązania w tym zakresie pozostają zdaniem Autorki wątpliwe w kontekście zasady niezależności związków zawodowych oraz zasady proporcjonalności.

Słowa kluczowe: działacz związkowy, wynagrodzenie, pracodawca, praca zarobkowa, proporcjonalność.

\section{GENERAL REMARKS}

One of the instruments aimed at facilitating trade union activity is the obligation imposed by the legislator on employers to cover the costs of the remuneration of trade union activists for periods of release from the obligation to perform work for the

${ }^{*}$ Cracow University of Economics, Department of Public Economic and Labour Law; medralam@uek.krakow.pl

${ }^{1}$ Cfr. Article 2 of the Convention no. 135 of the International Labour Organisation concerning protection and facilities to be afforded to workers' representatives in their undertaking of 23 June 
purposes of the performance of the office held in the trade union. The Act on Trade Unions of 23 May 1991 (Journal of Laws of 2019, item 263; hereinafter "ATU") provides for two kinds of paid release from the obligation to perform work with respect to the performance of the office held in the trade union while retaining the right to remuneration. The two kinds are: release from work for the time necessary to carry out $a d$ hoc activity resulting from his or her office held in the trade union (Article 25 sections 5-6 and Article 31 sections 3-4 ATU) ${ }^{2}$ and release from work for the time necessary to perform a full time office held in the trade union for members of the trade union management board (Article 31 sections 1-2 ATU). ${ }^{3}$ Since the amendment to the ATU of 5 July 2018 (the Act on the amendment of the Act on Trade Unions and some other acts of 5 July 2018, Journal of Laws of 2018, item 1608) the right to paid release on this basis has been granted not only to employees but also to other persons who perform gainful work. The costs on this account are also borne by employers, whose definition as a subject was changed on this occasion. ${ }^{4}$

In this context, it is interesting to consider the legal nature of the remuneration paid by employers in the case of such release. Namely, is this really remuneration for work sensu stricto which should on principle be characterised by payment, gainfulness, mutuality and a certain degree of equivalence (cfr. for example Wagner 1996, 1-2, 10)? Or perhaps, in fact, the employers bear the costs of benefits of public/social character i.e. work-related benefits other than remuneration for work sensu stricto (cfr. the title of Division III of the Labour Code; cfr. Mędrala 2020, 116-119, 139-144, 477-478). From this perspective one may pose further questions concerning the regularity of a construction currently adopted by the legislator concerning the sources of financing for the release under discussion in the context of, on the one hand, the principle of trade union independence (Article 1 section 2 ATU) and, on the other hand, from the perspective of the principles of proportionality and subsidiarity. ${ }^{5}$ I subject these questions to analysis in this article. In the text I use the classical method of synthesis and analysis.

1971, ratified and binding in Poland from the $9^{\text {th }}$ of June 1978 (Journal of Laws of 1977, no. 39, item 178); http://www.mop.pl/doc/html/konwencje/k135.html [Accessed: 1 August 2020].

${ }^{2}$ Which is granted to each employee who holds any office in the trade union (cfr. Góral 2012, 470).

${ }^{3}$ Under Article 34 section 1 these provisions are also applicable to an inter-establishment trade union organisation whose activity covers the employer.

${ }^{4}$ Under Article $1^{2}$ point 2 ATU the employer needs to be understood as the employer defined under Article 3 of the Act of 26 June 1974 - the Labour Code (Journal of Laws of 2020, item 1320 as amended) and an organizational unit, even without legal personality, as well as a natural person, if they employ a person other than an employee who performs gainful work, irrespective of the employment basis.

${ }^{5}$ More on these principles in the context of labour law: Mędrala 2020, 321-338. 


\section{THE COSTS OF REMUNERATION FOR TRADE UNION ACTIVISTS FINANCED BY EMPLOYERS}

Under Article 25 section 5 ATU, an employee has the right to be released from work while retaining the right to remuneration for the time required to carry out ad hoc activity resulting from his or her office held in the trade union outside the work establishment, if this activity cannot be performed during his or her free time. Under the newly added provisions of sections 6-7 Article 25 ATU, this right is also granted to "a person other than an employee who performs gainful work". Such a person, like an employee, "retains" the right to remuneration in such a situation. Exceptions are the situations provided for under special provisions, grounded in the special character of a given contract, dependent on the effects of work, for example a contract for specific work. ${ }^{6}$

Furthermore, the legislator determined that a contract entered into between an employer and a person other than an employee who performs gainful work in which a time limit for the performance of the work was determined is not extended by the time of the release from work (Article 25 section 7 ATU). Moreover, the provisions of a collective labour agreement may determine the limits of the time of release from work for the time necessary to carry out $a d$ hoc activity resulting from his or her office held in the trade union for the persons who perform gainful work (Article 25 section 8 ATU), which - considering the many doubts in this area which exist in practice - (cfr. for example Żołyński 2013, 516-519; Piątkowski 2012, 474-510; Grzebyk 2019a, commentary to Article 25 ATU, thesis 4; the judgement of the Supreme Court of 6 June 2001, I PKN 460/00; Prokuratura i Prawo 12 (2002): 48, LEX no. 52259; Książek 2019, commentary to Article 25 ATU, thesis 3; Żołyński 2019, 48-52) may be a very useful solution.

In similar conditions under Article 31 sections 3-4 ATU, both an employee and a person other than an employee who performs gainful work have the right to be released from work for the time required to perform a casual activity resulting from the office held in the trade union if such an activity cannot be performed during free time.

In each of the cases specified above, the employer is obliged for the period of release to pay, instead of the regular remuneration for work, a benefit which is its equivalent, even though the employee or different person performing gainful work does not perform the contracted work.

Apart from the costs of the release for the purpose of ad hoc activities resulting from the office held in the trade union, employers also cover the costs of the remuneration of so called full time trade union activists (more in: Rączka 2013,

${ }^{6}$ View the grounds for the draft act (filed by the Prime Minister on 12 October 2017) on the amendment to the Act on Trade Unions and some other acts, RM -10-117-17, 25; https://www.sejm. gov.pl/Sejm8.nsf/druk.xsp?nr=1933 [Accessed: 26 December 2020]. 
19-24). Under Article 31 section 1 ATU, depending on the number of members of an establishment's trade union organisation employed by the determined employer, the right to be released from the obligation to perform work for the term of office on the management board of an establishment's trade union organisation is granted. A similar right under the amendment referred to is granted to a person who performs gainful work during the period of release from work and who holds the right to remuneration or a financial benefit, if the board of the establishment's trade union organisation so requested (Article 31 section 2 point 2 ATU). ${ }^{7}$

Undoubtedly, the institutions under discussion seek to guarantee to a person who performs gainful work a source of maintenance at the same level as if he or she were working normally, even though he or she does not perform work due to the performance of social functions or partly public functions. On the other hand, benefits (remuneration) for the periods of performance of tasks by social labour inspectors are typically of a social nature. ${ }^{8}$

An essential novelty of the binding regulations is that the right to the benefits under discussion granted instead of remuneration for work is extended to each person who performs gainful work and who is a trade union activist. The provisions of the ATU introduce the notion of "a person who performs gainful work" as not only an employee within the meaning of the Labour Code but also a person who performs gainful work under a basis other than the employment relationship; if he or she does not employ other persons for this kind of work, irrespective of the employment basis and he or she holds the rights and interests connected with the performance of work which may be represented and protected by a trade union (Article $1^{1}$ point $1 \mathrm{ATU}$ ). In the literature it is pointed out that the extension of the scope of the subjective right to unite may contribute to increasing the level of employed persons; to reinforce the autonomy of trade unions which may independently decide (as they have a broader choice) on the circle of the

${ }^{7}$ Detailed principles are provided for in the Regulation of the Council of Ministers of 27 November 2018 on the regime by which the release from the obligation to perform work is granted and enjoyed for the term of office held in the management board of the establishment's trade union organisation to which a person who performs gainful work is entitled; in which the amount of remuneration or a financial benefit granted to a person for the period of release from work is determined; and the respective rights and benefits are upheld (Journal of Laws of 2018, item 2323), hereinafter "Regulation". Under $\S 5$ of the Regulation the employee's remuneration for the period of release from work is determined under the principles applicable when calculating a financial equivalent for an annual leave which has not been used by the employee. Under $\S 6$ of the Regulation, however, for a person other than an employee who performs gainful work for the period of release from work a monthly financial benefit is determined based on the amount of the average remuneration granted to such person for the period of 6 months previous to the period of release and if such person performs work for a period shorter than six months - based on the amount of the average remuneration granted to such person for all this period.

${ }^{8}$ The above was subject to my considerations in: Mędrala 2020, 479. Cfr. more on the institution of the social labour inspection, including the remuneration of social labour inspectors: Liszcz 2019, 2-11. 
represented and protected persons (Grzebyk, Pisarczyk 2019, 82). This means a gradual expansion of the working law in its broader meaning (which provides for working relationships based not only on the employment contract but also other bases) on the labour law in its narrower meaning. In any case, within the doctrine, the term of "collective working law" is already being used (Baran 2018, 4; Baran 2019b; Baran 2019a, 591 and the following). In this context I do not evaluate the legitimacy of the direction of changes because, as I have already stated elsewhere, a different (maybe a better) way would be to introduce instruments targeted at preventing the avoidance of employment under the employment contract. ${ }^{9}$ At the same time, the above means the extension of the rights within the scope of the benefits under discussion, typical for the labour law, onto a group of nonemployees pointed out in the statute.

\section{ARGUMENTS FOR TREATING REMUNERATION FOR RELEASE AS REMUNERATION FOR WORK}

While analysing the legal nature of the release of a trade union activist for the term of office held in the establishment's trade union organisation, the Supreme Court points out that

the right to be released from the obligation to perform work is an employee's (trade union activist's) subjective right - which is granted to him or her by will of the legislator, if the conditions referred to in Article 31 section 1 ATU are met, involving the modification of the content of the employment relationship (Article $22 \S 1$ of the Labour Code) in such a way that - while still being in this relationship - an employee does not perform its basic element i.e. he or she does not perform work for the benefit of the employer and the employer is still obliged to pay the remuneration to the employee (the judgement issued by the Supreme Court on 19 June 2012, II PK 270/11, Legalis no. 537275 and the documents referred to in its grounds: the resolution of the Supreme Court in the panel of 7 judges of 20 January 1999, III ZP 25/98, OSNAPiUS 1999 no. 17, item 541; the judgements of the Supreme Court: of 5 June 1996, I PRN 37/96, OSNAPiUS 1997, no. 3, item 36 and of 4 April 2002, I PKN 233/01, OSNP 2004, no. 6, item 96).

On the other hand, in the context of the legal nature of the remuneration for full time trade union activists, it is interesting to consider the justification of the resolution of the Supreme Court of 13 December 2005, II PZP 9/05 (OSNP 2006, no. 7-8, item 109), in which the Supreme Court stated that an employee released from the obligation to perform work as a member of the management board of the establishment's trade union organisation performs at the given employer's location

${ }^{9}$ More in: Mędrala 2020, 69-77. In the context of the right to unite for the self-employed a particularly careful attitude is suggested, as a certain interference with market conditions is pointed out - cfr. Grzebyk, Pisarczyk 2019, 86; a similarly critical view in the context of the right to associate of persons employed under contracts for running an undertaking, management or similar contracts - Baran 2019a, 597. 
"the duties within the scope of the protection of widely understood employees' rights and interests, their representation in disputes with the employer, the observance of labour law provisions and other duties entrusted to this organisation under the provisions of the Act on Trade Unions". Ipso facto the Supreme Court treats the remuneration paid by the employer to employees on this account as remuneration for work (although it is a kind of work which is different from the one specified in the contract), clearly still recognising in it elements of equivalence and mutuality (cfr. Mędrala 2020, 477-478).

J. Żołyński points out that during the period of release from the obligation to perform work, the employee's employment relationship is temporarily modified but is not interrupted. The difference involves the lack of the employee's obligation to be ready to perform work. But it is still an employment relationship of a mutual nature, although there is no traditional equivalence of benefits (Żołyński 2014, commentary to Article 31 ATU, thesis 4). An employee is still present at work. He or she is still obliged to perform his or her duties within the framework of Occupational Health and Safety, to register his or her working time, etc. He or she also holds the right to annual leave (cfr. Żołyński, commentary to Article 31 ATU, thesis 5-8). This is also confirmed by $\S 3$ of the executive regulation of 27 November 2018, under which a person who performs gainful work and who benefits from the release from the obligation to perform work and is present in the workplace observes the determined organisation and order in the process of work, as well as the provisions on occupational health and safety and fire regulations.

An additional argument for treating this type of remuneration as remuneration for work is also the fact that the employer may include the costs borne on this account among the revenue earning costs which in fact means that if the release is granted a higher level of remuneration than is provided for in the statutory provisions, it will not be included among such costs (cfr. Żołyński 2014, commentary to Article 31 ATU, thesis 10 and the letter of the Fiscal Administration Chamber in Katowice of 28 June 2010, IBPBI/2/423-507/10/MO, https://sip-1lex1pl-1ym3yi9cc13ca.han.uek.krakow.pl/\#/guideline/184590926?cm=DOCUMENT [Accessed: 9 April 2021]).

Its remunerational nature is also supported by the provision of section $2 \S 5$ of the Regulation under which the remuneration is determined again, if the principles of remuneration of all employees or an occupational group are modified and the employee would be subject to this modification if he or she were not enjoying the release. It means, therefore, that the legislator does not create a specific trade union post, rather an employee/a non-employee continues to perform work for which he or she was employed under the contract. His or her situation in the light of the principle of equal treatment for the purposes of remuneration should be compared to employees employed in posts analogous to his/her post indicated in the stipulated employment contract. 
Remuneration for trade union activists in the situations under discussion is subject to taxation and social security contributions like regular remuneration. Therefore, from a normative point of view, we may still consider it as remuneration for work.

Similar arguments may be presented in the case of release from work for the time necessary to carry out ad hoc activities resulting from the office held in the trade union.

\section{ARGUMENTS FOR TREATING REMUNERATION FOR RELEASE AS A WORK-RELATED BENEFIT OF PUBLIC/SOCIAL NATURE}

In the judgement of the Supreme Court of 19 June 2012, II PK 270/11, Legalis no. 537275, it was, among other things, pointed out that "the performance of an activity for the benefit of an entity other than the employer is not the performance of work for the benefit of the employer and consequently it is not the performance of occupational duties resulting from the employment relationship". Considering the lack of the features of mutuality and equivalence which are typical for remuneration for work, in my view there are some arguments to support the thesis that the benefits paid to employees on this account are of a public nature (including above all - its social aspect) whose cost is covered by employers (Mędrala 2020, 477-478). It is one of the examples where the public/social burden is imposed by the state on employers' property. In the literature concerning social politics, public, social and welfare issues (from the broadest to the narrowest definition) are distinguished (Szarfenberg 2018, 36). The payment of remuneration on the basis under discussion fulfils typically public purposes; mainly social purposes which are a subgroup of widely understood public purposes. It is impossible to find therein any direct equivalence and mutuality from an economic point of view.

The view that the remuneration of an employee or a different person who performs gainful work is a work-related benefit is in a certain way supported by the way in which the remuneration for such periods is calculated, i.e. the right to additional remuneration for work in conditions that are: harmful to health, particularly strenuous, strenuous or dangerous is granted only if, for the period of release from work, the employee's previous exposure to such conditions does not stop; on the condition that it is indicated that such conditions continue or would continue to affect him or her while performing the activities resulting from his or her office held in the management board of the establishment's trade union organisation. $^{10}$

${ }^{10} \S 5$ of the Regulation of the Council of Ministers of 27 November 2018 on the regime in which the release from the obligation to perform work is granted and enjoyed for the term of office held in the management board of the establishment's trade union organisation to which a person who performs gainful work is entitled; in which the amount of remuneration or financial benefit 
In my view, when releasing from work (granting a paid leave, an ad hoc release) an employee or a different person who performs gainful work, the employer releases the employee from work under payment for the purposes of performance of activities of a social or even public nature. And of such nature are activities performed by trade union activists when released from work. The tasks which are performed by trade unions are oriented towards public interests, including primarily social interests. The public activity of trade unions includes activity within the Social Dialogue Council, i.e. expressing opinions on draft acts of law (Article 19 sections 1-3 ATU). Also, trade unions have the right to publicly express their opinions on the assumptions or draft acts of law in the mass media, including radio and television (Article 19 section 4 ATU); the right to express opinions on consultative documents of the European Union (Article $19^{1}$ ATU); the right to submit motions to pass or amend a law (Article 20 ATU). Trade unions monitor compliance with labour law (Article 23 ATU); they have the right to conduct collective negotiations and conclude collective bargaining agreements, as well as other agreements stipulated by the labour law provisions (Article 21 ATU); or they contribute to widely understood protection of work under Article 24 of the Constitution of the Republic of Poland. Among a series of tasks performed by trade unions as the subject of social policy there are: the representation and defence of working people's rights, as well as their occupational and social interests - Article 1 section 1 ATU (participation in labour market policy); the supervision of occupational health and safety (participation in pro-health policy); the maintenance of social peace within social dialogue; participation in human resources management (cfr. Piątkowski 2014, 109-111). The activity of trade union organisations is aimed at ensuring the constitutional protection of freedom of association in trade unions (Article 59 of the Constitution of the Republic of Poland), at exercising the social rights of working people to unite. This is also confirmed by the fact that a request for the paid release from work of a trade union activist must be filed with the employer by the management board of the establishment's trade union organisation (as a kind of social, and partially public body) and not the employee on his/her own (cfr. Żołyński 2011, 96). In the doctrine, one may even find a view that trade unions, through their imperative powers within the freedom of labour (e.g. they may approve the revoking of special protection before the termination of the employment relationship), exercise - to a certain degree - public power (Sobczyk 2014, 2-11).

Thus, I think that in this case we are dealing with a work-related benefits that are different from remuneration for work (in its exact meaning). They are nonreciprocal, not equivalent, aimed at achieving public goals (including especially social goals), obligatory, based on statutory provisions (cfr. Mędrala 2020, 112). It

granted to a person for the period of release from work is determined along with the respective rights and benefits, Journal of Laws of 2018, item 2323; Baran 2020, commentary to $\S 5$ of the Regulation, thesis 3 . 
may be stated that the state imposes on the employers the burden of public/social benefits connected with the performance of some public/social roles.

Both an employee as well as a person who performs gainful work under a different basis perform in this time tasks of a public nature (mainly of a social nature) as part of the constitutional protection of work and which at the same time are included in the activity of trade unions which under the statutory definition is characterised by independence from the employer (cfr. Article 1 section 2 ATU). Therefore, in my opinion, there are arguments to support the view that the employers de facto cover the costs of public/social benefits of an individual nature.

\section{THE COSTS OF REMUNERATION FOR TRADE UNION ACTIVISTS VERSUS THE PRINCIPLE OF TRADE UNION INDEPENDENCE AND PROPORTIONALITY}

Taking the above into account, I support the view that in this context the fact that the employers cover the costs on this account is questionable in the light of the principle of the independence of trade unions (Article 1 section 2 ATU) and that it is a disproportionate burden on employers in the current market situation.

Z. Góral emphasises a broad subjective range of $a d$ hoc releases which apply irrespective of the number of trade union members employed in the establishment (Góral 2012, 470) which is highly questionable in the context of the principle of proportionality. K.W. Baran, on the other hand, suggests the introduction of a maximum limit to the number of activists who enjoy such releases under Article 31 section 1 ATU (Baran 2013, 569). In this context it also needs to be pointed out that the number of terms of office of full time trade union activists is currently not limited in any way, which means that the employer might be obliged in some cases to pay to such persons the benefits which are an equivalent of their remuneration for over ten years or even for decades. ${ }^{11}$

In the literature it is also pointed out that the financial support granted to trade unions i.e. the coverage by the employer of the costs of full time trade union activists is rooted in the 1990s (Grzebyk, Pisarczyk 2019, 91). At that time it was justified by the difficult situation of trade unions and the interim character of this solution was emphasised (Grzebyk, Pisarczyk 2019, 91). According to the representatives of the doctrine, in the current conditions of the market economy and parity of social partners this solution remains questionable (Grzebyk, Pisarczyk 2019, 86).

P. Grzebyk is right to indicate the controversies connected with the costs of so called full time trade union activists. The Author in particular refers to the solutions provided for in Article 2 section 1 of Convention no. $98^{12}$ which states

${ }^{11}$ K.W. Baran opts for the limitation of such rights to two terms of office (Baran 2014, 935).

${ }^{12}$ The Convention no. 98 of the International Labor Organization concerning the application of the principles of the right to organize and collective bargaining, adopted at Geneva on 1 July 1949 (Journal of Laws of 1958, no. 29, item 126). 
that workers' and employers' organisations shall enjoy adequate protection against any acts of interference by each other or each other's agents or members in their establishment, functioning or administration (section 1). In my opinion the Author is right to question the fact that the employers bear the main costs on this account, even if it is recognised that trade unions care about the public interest (e.g. fair redistribution, the observance of the labour law provisions) and perform public tasks within the realm of the protection of work. Such doubts are, according to the Author, even more understandable in the light of the fact that trade unions hold not only conciliatory powers which may deepen a social dialogue but also confrontational powers, e.g. via strikes. The Author claims that remuneration for the performance of trade union activity should be in the first place paid by the trade union and not by the employer. ${ }^{13}$ Also, the Author's further considerations should be deemed as fair, i.e. that the release from the obligation to perform work under Article 31 sections 1-2 ATU fulfils a public interest rather than an employer's private interest (Grzebyk 2019b, commentary to Article 31 ATU, thesis 4). The views referred to hereinabove of the quoted Author are also arguments to support the thesis that when covering the costs of the release from work of full time trade union activists the employing entities in fact do not pay them remuneration for work rather a work-related benefit of a public/social nature.

Moreover, even if we accept the view that trade unions hold private status, ${ }^{14}$ financing of private entities' activity which acts contrary to their interests is even more questionable in the light of trade union independence. It also needs to be indicated that there is quite a low level of unionisation. ${ }^{15}$ In many establishments employees are represented by works councils or representatives elected under special provisions for determined purposes to represent employees' rights and interests. Employers are obliged, however, to finance such benefits only in the case of trade unions.

In this context I consider it to be a fairer solution where an employee is released from the obligation to perform work without the right to remuneration or only to partial remuneration. The costs of remuneration on this account could be $d e$ lege ferenda covered - at least partially - by funds from the national budget, local

${ }^{13}$ Grzebyk 2019b, commentary to Article 31 ATU, thesis 2. Whereas K.W. Baran opts for the limitation of trade union leaves to the establishment's level (Baran 2013, 569).

${ }^{14}$ Such view in e.g. Z. Hajn $(2013,58-59)$.

${ }^{15}$ In 2013 K.W. Baran indicated the number of 15\% (Baran 2013, 568); similarly in 2014 - J. Żołyński. The Author indicated 15\%, including 5-10\% of so called "yellow trade unions" (Żołyński 2014, 83). This number is, however, gradually decreasing. According to the report issued by CBOS - a statement from the research no. 87/2017 - Działalność zwiazków zawodowych w Polsce [The activity of trade unions in Poland], Warsaw, July 2017, 1 and the following - a membership in a trade union is declared by $5 \%$ of citizens. Whereas according to the latest report issued by CBOS - a statement from the research no. 138/2019 - Działalność zwiazków zawodowych w Polsce [The activity of trade unions in Poland], Warsaw, November 2019, 1 and the following - a membership in a trade union is declared by $6 \%$ of citizens. 
authorities or trade union funds. The current solution, as it excessively burdens employers, also generates doubts in the context of the principles of proportionality and subsidiarity. ${ }^{16}$ This problem is also noticed by practicians who opt for an increase in the minimum number sufficient to create so called full time trade union posts, which compared to other European countries, is quite rare in Poland. ${ }^{17}$

\section{CONCLUSIONS}

The conducted analysis leads to a few conclusions.

It is a justified thesis that the benefits paid to employees and persons employed under a different basis in place of the remuneration for work, when such a person is released for the time necessary to perform ad hoc activities resulting from the office held in the trade union as well as the remuneration for so called full time trade union activists are in fact work-related benefits of a social (even public) nature. In the context of the title of Division III of the Labour Code they need to be classified as "other work-related benefits". They are benefits of a public/social nature because the tasks performed by trade union activists released from work for such purposes as well as the activity itself carried out by an establishment's trade union organisations are of a public/social nature.

In principle, it needs to be evaluated favourably that the benefits under discussion are extended to the persons who work under a basis other than an employment relationship. In this area, the situation of the persons for whom the

${ }^{16} \mathrm{Cfr}$. my conclusions with this respect in the context of the remuneration of full time trade union activists (Mędrala 2020, 478).

${ }^{17}$ In this place I refer to my discussions with lawyers-practitioners concerning collective labour law, including with Janusz Żołyński, Hab. PhD. Cfr. also the data from the European Trade Union Institute: in the Czech Republic the paid release from work is granted on a part-time basis, if the trade union unites 400-600 members, one full time post is granted in the case of 600 members, two full time posts, if the trade union unites up to 1500 members; http://www.worker-participation. eu/National-Industrial-Relations/Countries/Czech-Republic/Workplace-Representation [Accessed: 8 August 2020]; in Austria: one paid full time post, if 150-700 trade union members are employed. If 701-3000 members are employed - two full time posts are granted, if more than 3000 - three full time posts; an additional full time post for all 3000 members; http://www.worker-participation.eu/ National-Industrial-Relations/Countries/Austria/Workplace-Representation [Accessed: 8 August 2020]. In France the trade union delegates are granted 12 hours of paid release monthly, if 50150 employees are employed; 18 hours of paid release monthly, if 151-499 employees are employed; 24 hours monthly, if more than 500 employees are employed; http://www.worker-participation.eu/ www.worker-participation.eu/index.php/National-Industrial-Relations/Countries/France/Workplace-Representation [Accessed: 8 August 2020]. In Italy one paid hour annually is granted for each employee, if less than 200 employees are united; eight hours monthly for all 300 employees, if less than 3.000 employees are united; eight hours monthly for all 500 employees, if more than $3.000 \mathrm{em}-$ ployees are united; http:/www.worker-participation.eu/www.worker-participation.eu/index.php/ National-Industrial-Relations/Countries/Italy/Workplace-Representation [Accessed: 8 August 2020]. 
work from a determined source is a permanent source of income should not differ. However, some detailed issues such as e.g. trade union rights for the self-employed need to be subject to separate analysis.

On the other hand, it should be evaluated negatively that the legislator continues to maintain the status quo concerning the sources of financing of such costs. I think that the current model of employment relationships, or in fact working relationships in their more extensive meaning, needs to be modified in this respect. What still needs to be considered de lege ferenda is the limitation of the entire financing of so called full time trade union activists from the employers' means to their previous extent or their limitation via an increase in quantity limits for the right to paid release on this account. This is supported by the low level of unionization, the lack of similar guarantees for other non-trade union employees' representations, the abuse of full time trade union posts in practice, excessive privileges granted to Polish trade union activists and the excessive burden imposed on employers in this respect compared to other countries. The above also remains questionable in the context of the principle of trade union independence as well as the principles of subsidiarity and proportionality.

\section{BIBLIOGRAPHY}

Baran, Krzysztof W. 2013. "O potrzebie nowelizacji prawa związkowego". Monitor Prawa Pracy 11: $568-572$.

Baran, Krzysztof W. 2014. "Status prawny przedstawicieli pracowników”. In System Prawa Pracy. Tom V. Zbiorowe prawo pracy. Edited by Krzysztof W. Baran. 913-944. Warszawa: Wolters Kluwer Polska.

Baran, Krzysztof W. 2018. "O zakresie prawa koalicji w związkach zawodowych po nowelizacji prawa związkowego z 5 lipca 2018 r.”. Praca i Zabezpieczenie Społeczne 9: 2-4.

Baran, Krzysztof W. 2019a. Ed. Prawo pracy i ubezpieczeń społecznych. Warszawa: Wolters Kluwer Polska.

Baran, Krzysztof W. 2019b. Ed. Zbiorowe prawo zatrudnienia. Komentarz. Warszawa: Wolters Kluwer Polska.

Baran, Krzysztof W. 2020. “Komentarz do $§ 5$ rozporządzenia, teza 3. Komentarz do rozporządzenia w sprawie trybu udzielenia i korzystania ze zwolnienia z obowiązku świadczenia pracy na okres kadencji w zarządzie zakładowej organizacji związkowej przysługującego osobie wykonującej pracę zarobkową, sposobu ustalenia wysokości wynagrodzenia albo świadczenia pieniężnego przysługującego osobie w okresie zwolnienia od pracy oraz wynikających z tego tytułu uprawnień i świadczeń". In Prawo pracy. Rozporządzenia. Komentarz. Edited by Krzysztof W. Baran. Warszawa: Wolters Kluwer Polska, LEX/el.

Działalność zwiąków zawodowych w Polsce. 2017. Raport CBOS. Komunikat z badań nr 87/2017. Warszawa: Fundacja CBOS.

Działalność zwiazków zawodowych w Polsce. 2019. Raport CBOS. Komunikat z badań nr 138/2019. Warszawa: Fundacja CBOS.

Góral, Zbigniew. 2012. "Ułatwienia w działalności zakładowej organizacji związkowej - wybrane uwagi na tle przepisów ustawy o związkach zawodowych”. In Związkowe przedstawicielstwo pracowników zakładu pracy. Edited by Zbigniew Hajn. 459-473. Warszawa: Wolters Kluwer Polska. 
Grzebyk, Piotr. 2019a. "Komentarz do art. 25 u.z.z., teza 4". In Ustawa o zwiąkach zawodowych. Komentarz praktyczny z orzecznictwem. Paweł Czarnecki, Piotr Grzebyk, Anna RedaCiszewska, Barbara Surdykowska. Warszawa: C.H. Beck, Legalis/el.

Grzebyk, Piotr. 2019b. “Komentarz do art. 31 u.z.z., tezy 2, 4”. In Ustawa o zwiazkach zawodowych. Komentarz praktyczny z orzecznictwem. Paweł Czarnecki, Piotr Grzebyk, Anna RedaCiszewska, Barbara Surdykowska. Warszawa: C.H. Beck, Legalis/el.

Grzebyk, Piotr. Łukasz Pisarczyk. 2019. "Krajobraz po reformie. Zbiorowa reprezentacja praw i interesów zatrudnionych niebędących pracownikami”. Praca i Zabezpieczenie Społeczne 1: $81-98$.

Hajn, Zbigniew. 2013. Zbiorowe prawo pracy. Zarys systemu. Warszawa: Wolters Kluwer Polska.

Książek, Daniel. 2019. "Komentarz do art. 25 u.z.z., teza 3". In Zbiorowe prawo zatrudnienia. Komentarz. Edited by Krzysztof Wojciech Baran. Warszawa: Wolters Kluwer Polska, LEX/el.

Liszcz, Teresa. 2019. "Społeczna inspekcja pracy-niezbędny instrument społecznego (związkowego) nadzoru nad przestrzeganiem prawa pracy". Praca i Zabezpieczenie Społeczne 4: 2-11.

Mędrala, Małgorzata. 2020. Spoleczny charakter świadczeń $w$ polskim prawie pracy. 2nd Ed. Warszawa: Wolters Kluwer Polska.

Piątkowski, Jan. 2012. "Doraźne zwolnienia od pracy w ustawie o związkach zawodowych". In Zwiąkowe przedstawicielstwo pracowników zakładu pracy. Edited by Zbigniew Hajn. 474510. Warszawa: Wolters Kluwer Polska.

Piątkowski, Jan. 2014. "Polityka społeczna a zbiorowe prawo pracy". In System Prawa Pracy. Tom V. Zbiorowe prawo pracy. Edited by Krzysztof W. Baran. 97-128. Warszawa: Wolters Kluwer Polska.

Rączka, Krzysztof. 2013. “Urlopy bezpłatne i zwolnienia od pracy działaczy związkowych”. Praca i Zabezpieczenie Spoleczne 11: 19-24.

Surdykowska, Barbara. 2019. "Komentarz do art. 33 u.z.z., teza 5". In Ustawa o zwiazkach zawodowych. Komentarz praktyczny z orzecznictwem. Paweł Czarnecki, Piotr Grzebyk, Anna Reda-Ciszewska, Barbara Surdykowska. Warszawa: C.H. Beck, Legalis/el.

Szarfenberg, Ryszard. 2018. Pojęcie polityki społecznej. In Polityka społeczna. Edited by Grażyna Ferlit-Fesnak, Jacek Męcina. 25-44. Warszawa: Wydawnictwo Naukowe PWN.

Wagner, Barbara. 1996. "Ekwiwalentność wynagrodzenia i pracy". Praca i Zabezpieczenie Spoleczne 6: 1-11.

Żołyński, Janusz. 2011. Pracodawca a zwiazki zawodowe. Wybrane problemy zbiorowego prawa pracy. Zagadnienia prawne $w$ pytaniach $i$ odpowiedziach, wzory pism. Warszawa: Wolters Kluwer Polska.

Żołyński, Janusz. 2013. “Zwolnienie działacza związkowego z obowiązku świadczenia pracy w celu dokonywania czynności doraźnych”. Monitor Prawa Pracy 10: 516-519.

Żołyński, Janusz. 2014. "Strajk i inne akcje protestacyjne w praktyce przedsiębiorstw". In Aktualne problemy reprezentacji pracowniczej w zbiorowych stosunkach pracy. Edited by Jerzy Wratny. 77-94. Warszawa: Instytut Pracy i Spraw Socjalnych.

Żołyński, Janusz. 2014. Ustawa o zwiazkach zawodowych. Komentarz. Warszawa: Wolters Kluwer Polska, LEX/el.

Żołyński, Janusz. 2019. "Doraźne zwolnienie działacza związkowego od pracy z zachowaniem prawa do wynagrodzenia - glosa - II PK 322/16”. Monitor Prawa Pracy 3: 48-52. 